\title{
Antibacterial Studies on Toona Ciliata. Roemer.
}

\author{
Christopher Patrick kiladi* \\ Department of Botany, St.Xavier's College, Tirunelveli-627002.India
}

\begin{abstract}
The use of higher plants and their extracts to treat infectious is an age old practice in traditional Indian medicine. The aromatic and medicinal plants represent enormous reservoir of potential microbicidal compounds that could be useful alternative to synthetic microbicides and are being used to develop drugs. In the present study Toona ciliata Roemer. leaf, stem and root powder extracts were tested against ten different randomly selected bacteria by disc diffusion method. It was found the methanol extract strongly effective against all the chosen bacteria. The Minimum inhibitory concentration value ranges from $10 \mathrm{mg} / \mathrm{ml}$ to $35 \mathrm{mg} / \mathrm{ml}$.
\end{abstract}

Key words: Antibacterial study, Minimum Inhibitory Concentration

\section{Introduction}

Medicinal plants and herbal plants has assumed greater importance in recent days, due to the tremendous potential they offer in formulating new drugs against many disease and illness that affect the human kind. Plants have been used in the traditional health care system from time immemorial, particularly among tribal communities. In view of the rich diversity of Indian medicinal plants it is expected that screening and scientific evaluation of plant extract for their antimicrobial substance may prove beneficial for the mankind. Further, synergistic interaction among crude extracts or phytoconstituents in vitro may be useful in the preparation of improved polyherbal or drugs formulations. (Pradeep - Parihar et al., 2003).Thus, keeping this view in mind medical communities are now trying to seek the solution of above said problems from plants based on medicines in allopathy. Thus, keeping this view in mind medical communities are now trying to seek the solution of above said problems from plants based on medicines in allopathy.

\section{Materials and Methods}

Plant parts of Toona ciliata Roemer. Were collected from hills of Western Ghats. The Taxonomic identities of plants were confirmed by the 'Flora of Presidency and Flora of Carnatic (Gamble 1: 186 (133). 1915) for the Botanical verification and authenticating the plant material. Fresh plant materials were shade dried and homogenized to a fine powder.

Extracts were made from air dried samples. $60 \mathrm{~g}$ of the leaf stem and root (powdered test materials) was extracted successively with of $400 \mathrm{ml}$ of petroleum ether $\left(60-80^{\circ} \mathrm{c}\right)$, benzene, chloroform and methanol. This sequence of solvents allows for leaching all compounds based on their polarity. The individual fractions were collected and concentrated to obtain crude extracts. The above solvents were diluted and the final concentration was $5-10 \mathrm{mg} / \mathrm{ml}$ of solvents used for bacterial bio-assay. Filter paper disc of $6 \mathrm{~mm}$ diameter of Whatman filter paper No.1 were soaked in solution for an hour and dried at room temperature.

The antibacterial activity was tested against ten randomly selected bacterial strains such as Escherichia coli, Pseudomonas aeruginosa, Staphylococcus aureus, Streptococcus pyogenes, Salmonella typhii, Serratia marcescens, Klebsiella pneumonia, Enterobacter aerogenes, proteus vulgoris and Bacillus subtilis. The selected bacterial strains were obtained fromDepartemnt of Microbiology, Sri Paramakalyani College, Alwarkuruchi.

The media used for antibacterial tests were Muller Hinton (MH) agar (Himedia Laborotories Pvt. Ltd, India). Each organism was maintained in a respective culture medium and was recovered for testing by sub culturing on a fresh media.

Antibacterial assay was demonstrated by a modification of the method described by Bauer et al., (1966). $0.5 \mathrm{ml}$ of the dilute microbial culture was spread on sterile Muller Hinton Agar plates. The presoaked and dried discs were placed on the seeded plates and gently pressed down to assure contact.

Streptomycin $10 \mathrm{mg} / \mathrm{ml}$ was used as positive control and the respective solvents which were used to dissolve the crude extracts served as negative control. The plates were incubated at room temperature for $24 \mathrm{hrs}$. After the incubation period the inhibition zone around the discs were measured and recorded. Three replicates for each concentration were maintained.

\section{MINIMAL INHIBITORY CONCENTRATION (MIC)}

Antibiotic sensitivity test was performed by commonly used agar diffusion method (Ruckmani et. al., (1996) which is designed to determine the smallest amount of the antibiotic needed to inhibit growth of 
microorganisms. The resulting value is called the minimum inhibitory concentration (MIC). The test for minimum inhibitory concentration was carried out by using methanol extract against selected gram positive and gram negative organisms. To determine potential of extract, crude extract was diluted up to $100 \mathrm{mg} / \mathrm{ml}$, $35 \mathrm{mg} / \mathrm{ml} 20 \mathrm{mg} / \mathrm{ml}, 10 \mathrm{mg} / \mathrm{ml}$ and $5 \mathrm{mg} / \mathrm{ml}$. concentration by dissolving in methanol. Assay plates seed with bacterial cultures were incubated at room temperature for 12 hours. After incubation MIC was determined by measuring the zone of inhibition.

\section{Results and discussion}

Toona ciliata Roemer is an important medicinal plant which has been used for many centuries throughout the south pacific. It is a small shrub, three to five meters height. Results of antibacterial property of crude extracts and standard antibiotic (Streptomycin) were summarized in Table 1. Petroleum ether, Benzene, Chloroform, Ethanol and Distilled water, as pure solvent was not showed antibacterial activity.

Antibacterial activity of leaf extract: Extract of Toona ciliata Romerleaves in petroleum ether solvents was represented anti bacterial activity against four chosen bacteria. The Benzene extracts pronounced antibacterial activity by inhibiting the growth of almost all isolates used except Streptococcus pyogenes, and Salmonella typhii. Methanol extracts exhibited good antibacterial activity inhibited growth of all the isolates used. The aqueous extract was effective against all the bacterial cultures except Staphylococcus aureus, Enterobactor aerogenes and Bacillus subtilis.

Antibacterial activity of stem extract: Petroleum ether stem extracts had no activity against Klebsiella pneumoniae. The Benzene extract was inhibitory in the order Staphyloccus aureus < Pseudomonas aeruginosa $<$ Streptococcus pyogenes < Bacillus subtilis < Serratia marcescens. The chloroform extract showed inhibitory activity against all bacteria except Salmonella typhi. The methanol and water extracts showed inhibition zone against all the used bacterial cultures. The maximum inhibitory zone reported against Klebsiella pneumoniae in methanol extract while comparing with the other extracts

Antibacterial activity of root extract: Petroleum ether root extract showed antibacterial activity against Escherichia coli, Pseudomonas aeruginosa, Streptococcus pyogenes, Salmonella typhi, Enterobacter aerogenes and Bacillus subtillis. Benzene extract reported inhibitory zone against all bacteria except Staphylococcus aureus, Klebsiella pneumoniae and Enterobacter aerogenes. The chloroform extracts was moderately produce inhibition zone against all bacteria except Streptococcus pyogenes and Proteus vulgaris. All the test organisms were susceptible to methanol, water extracts and control drug.

Thirty-one species in twenty genera of the plant family Meliaceae were assayed for the production of growth-inhibiting phytochemicals. Most species were inhibitory when methanolic extracts were incorporated into artificial diets at concentrations at or below those occurring naturally. (Kraus et al., 1978).

The aqueous extract and ethanol extract exhibit a high degree of activity and this seems to confirm the traditional therapeutic claims of three herbs. Among the five tested extracts ethanol in root $(3.3 \mathrm{~mm})$, stem $(2.4 \mathrm{~mm})$ and Leaf $(2.8 \mathrm{~mm})$ registered maximum inhibitory effect on Bacillus subtilis, Klebsiella pneumoniae and Streptococcus pyogenes respectively.

This result is in agreement with the earlier reported of Hiremath et. al., (1997) that the higher plants have alkaloids and flavonoids which control the growth of microbial pathogen. Natural plant protecting agents are Toonacilin, $\mathrm{R} \equiv \mathrm{H}$, and its 6-acetoxy derivatives whose structure has now been elucidated. They occur in the bark of a Toona ciliata species; extracts exert a powerful ant feeding effect on the Mexican bean beetle.

Thirty-one species in twenty genera of the plant family Meliaceae were assayed for the production of growthinhibiting phytochemicals. Most species were inhibitory when methanolic extracts were incorporated into artificial diets at concentrations at or below those occurring naturally. (Kraus et al., 1978).

Table 1: Antibacterial activity of leaf, stem and root of Toona ciliata $\boldsymbol{L}$.

\begin{tabular}{|c|c|c|c|c|c|c|c|c|c|c|c|c|}
\hline \multirow{2}{*}{$\begin{array}{l}\mathrm{S} \\
\mathrm{NO}\end{array}$} & \multirow[t]{2}{*}{ Solvent name } & \multirow{2}{*}{$\begin{array}{l}\text { Plant } \\
\text { Part }\end{array}$} & \multicolumn{10}{|c|}{ Inhibition zone (m.m) } \\
\hline & & & 1 & 2 & 3 & 4 & 5 & 6 & 7 & 8 & 9 & 10 \\
\hline 1 & $\begin{array}{l}\text { Petroleum } \\
\text { ether } \\
(40-60)\end{array}$ & $\begin{array}{l}\text { Leaf } \\
\text { Stem } \\
\text { root }\end{array}$ & $\begin{array}{l}- \\
0.6 \\
1.3\end{array}$ & $\begin{array}{l}1.0 \\
0.6 \\
0.7\end{array}$ & $\begin{array}{l}1.5 \\
0.7 \\
-\end{array}$ & $\begin{array}{l}- \\
2.2 \\
0.7\end{array}$ & $\begin{array}{l}- \\
1.2 \\
1.2\end{array}$ & $\begin{array}{l}- \\
1.4 \\
-\end{array}$ & $\begin{array}{l}-1.2 \\
- \\
-\end{array}$ & $\begin{array}{l}- \\
0.8 \\
0.7\end{array}$ & $\begin{array}{l}- \\
1.0 \\
-\end{array}$ & $\begin{array}{l}2.0 \\
0.7 \\
0.7\end{array}$ \\
\hline 2 & $\begin{array}{l}\text { Benzene } \\
(79-81)\end{array}$ & $\begin{array}{l}\text { Leaf } \\
\text { Stem } \\
\text { root }\end{array}$ & $\begin{array}{l}0.7 \\
- \\
0.7 \\
\end{array}$ & $\begin{array}{l}0.9 \\
0.7 \\
1.0 \\
\end{array}$ & $\begin{array}{l}1.2 \\
0.6 \\
-\end{array}$ & $\begin{array}{l}- \\
0.9 \\
1.2 \\
\end{array}$ & $\begin{array}{l}- \\
- \\
1.0\end{array}$ & $\begin{array}{l}0.7 \\
1.4 \\
1.0 \\
\end{array}$ & $\begin{array}{l}1.4 \\
- \\
- \\
\end{array}$ & $\begin{array}{l}1.4 \\
- \\
- \\
\end{array}$ & $\begin{array}{l}0.8 \\
- \\
0.7 \\
\end{array}$ & $\begin{array}{l}- \\
1.2 \\
1.0 \\
\end{array}$ \\
\hline
\end{tabular}


Antibacterial Studies On Toona Ciliata. Roemer.

\begin{tabular}{|l|l|l|l|l|l|l|l|l|l|l|l|l|}
\hline 3 & Chloroform & Leaf & 1.0 & 0.8 & 1.2 & 0.9 & - & 1.2 & 0.9 & - & 1.2 & - \\
& $(59-61)$ & Stem & 0.7 & 1.0 & 0.9 & 0.8 & - & 0.7 & 1.1 & 0.5 & 0.5 & 05 \\
& & root & 0.8 & 0.5 & 1.0 & - & 0.9 & 1.4 & 1.9 & 1.1 & - & 1.3 \\
\hline 4 & ethanol & Leaf & 1.9 & 1.2 & 1.9 & 2.8 & 1.9 & 2.2 & 1.7 & 1.8 & 2.7 & 1.2 \\
& & Stem & 2.3 & 2.1 & 1.5 & 0.7 & 1.7 & 1.6 & 2.4 & 1.5 & 1.4 & 1.4 \\
& & root & 14 & 1.4 & 2.2 & 1.6 & 2.0 & 1.5 & 2.3 & 1.9 & 1.7 & 3.3 \\
\hline 5 & Distilled & Leaf & 1.1 & 1.0 & - & 0.9 & 1.2 & 1.2 & 1.5 & - & 1.8 & - \\
& water & Stem & 0.7 & 1.2 & 2.2 & 1.3 & 1.0 & 0.9 & 1.2 & 0.9 & 0.9 & 1.0 \\
& & root & 1.9 & 0.8 & 0.9 & 1.9 & 1.2 & 1.0 & 2.3 & 1.3 & - & 0.8 \\
\hline 6 & Positive & Leaf & 2.5 & 1.4 & 4.8 & 3.0 & 2.6 & 1.7 & 1.9 & 2.5 & 1.9 & 1.6 \\
& control & Stem & 2.9 & 1.5 & 4.0 & 2.3 & 2.7 & 3.0 & 2.11 & 2.0 & 3.0 & 3.7 \\
& & root & 0.9 & 3.5 & 2.2 & 2.7 & 2.8 & 3.3 & 2.4 & 2.5 & 1.0 & 2.6 \\
\hline
\end{tabular}

1.Escherichia coli. 2.Pseudomonas aeruginosa. 3.Staphylococcus aureus. 4.Streptococcus pyogenes. 5.Salmonella typhii. 6.Serratia marcescens. 7.Klebsiella pneumonia. 8 .Enterobacter aerogenes. 9. Proteus vulgoris and 10. Bacillus subtilis.

\section{Minimum Inhibitory Concentration:}

The lowest concentration of the herbal extract that inhibited the growth of micro organisms completely was regarded as minimum inhibitory concentration. The test were performed and presented in the table 2

The leaf methanol extract showed the minimal inhibitory concentration $10 \mathrm{mg} / \mathrm{ml}$ was less to Staphylococcus aureus, Salmonella typhii, Serrasia marcescens, Klepsiella pneumoniae and Bacillus subtillus when compared to that of other microorganisms tested. It was high to E.coli indicating tested that this microorganisms. The minimum inhibitory concentration of stem methanol extract was reported less to Staphylococcus aureus, Streptococcus pyogenes, Salmonella typhii, Kelbsiella pneumoniae and Enterobacter aerogenes with $100 \mathrm{mg} / \mathrm{ml}$ concentration, when compared to those of other microorganisms tested. The root methanol extract was strongly produce inhibitory towards Pseudomonas aureginoase, Ptreptococcus pyogenes, Salmonella typhii, Proteus vulgaris and Bacillus subtilis in the low concentration $10 \mathrm{mg} / \mathrm{ml}$.

Table 2.Minimum inhibitory concentration for methanol extracts of leaf, stem and root of Toona ciliata $\mathbf{L} .(\mathrm{mg} / \mathrm{ml})$

\begin{tabular}{|l|l|l|l|l|l|l|l|}
\hline $\begin{array}{l}\text { S } \\
\text { No }\end{array}$ & Bacteria & $\begin{array}{l}\text { Plant } \\
\text { part }\end{array}$ & $100 / 1$ & $35 / 1$ & $20 / 1$ & $10 / 1$ & $5 / 1$ \\
\hline 1 & E. coli & Leaf & 1.3 & - & - & - & - \\
& & Stem & 1.0 & 0.9 & 0.9 & - & - \\
& & root & 1.5 & 1.4 & - & - & - \\
\hline 2 & Pseudomonas & Leaf & 1.2 & 1.0 & 0.9 & - & - \\
& aeruginosa & Stem & 1.0 & 0.8 & - & - & - \\
& & root & 1.1 & 1.0 & 1.1 & 0.9 & - \\
\hline 3 & Staphylococcus & Leaf & 0.9 & 0.6 & 0.7 & 0.6 & - \\
& aureus & Stem & 0.7 & 0.8 & 0.7 & 0.7 & - \\
& & root & 2.1 & 1.5 & - & - & - \\
\hline 4 & streptococcus & Leaf & 1.3 & 1.0 & 0.9 & - & - \\
& pyogens & Stem & 1.2 & 1.0 & 0.9 & 0.8 & - \\
& & root & 1.2 & 1.1 & 1.0 & 0.9 & - \\
\hline 5 & Salmonella & Leaf & 1.4 & 0.9 & 1.0 & 0.8 & - \\
& typhii & Stem & 2.0 & 1.0 & 1.0 & 0.9 & - \\
& & root & 1.6 & 1.2 & 1.2 & 1.1 & - \\
\hline 6 & Serratia & Leaf & 1.4 & 0.8 & 0.6 & 0.6 & - \\
& Marcescens & Stem & 1.2 & 1.0 & 0.8 & - & - \\
& & root & 1.1 & 0.9 & 0.9 & - & - \\
\hline 7 & Klebsiella & Leaf & 1.9 & 1.3 & 0.6 & 0.6 & - \\
& pneumoniae & Stem & 2.0 & 1.0 & 1.2 & 0.9 & - \\
& & root & 1.5 & 1.1 & 0.9 & - & - \\
\hline 8 & Enterobacter & Leaf & 1.7 & 1.0 & 0.9 & 0.7 & - \\
& aerogenes & Stem & 2.0 & 1.9 & 0.7 & 0.6 & - \\
& & root & 1.2 & 0.9 & 0.9 & - & - \\
\hline
\end{tabular}


Antibacterial Studies On Toona Ciliata. Roemer.

\begin{tabular}{|l|l|l|l|l|l|l|l|}
\hline 9 & Proteus & Leaf & 1.2 & 1.0 & - & - & - \\
& vulgaris & Stem & 1.0 & 0.8 & 0.7 & - & - \\
& & root & 1.3 & 1.2 & 1.2 & 1.1 & - \\
\hline \multirow{2}{*}{10} & \multirow{2}{*}{ Bacillus subtilis } & Leaf & 1.3 & 1.9 & 0.9 & 0.6 & - \\
& & Stem & 1.0 & 0.6 & - & - & - \\
& & root & 1.3 & 1.2 & 1.1 & 1.0 & - \\
\hline
\end{tabular}

The results of present study reveal that the employed extracts of Toona ciliata exhibited potential antibacterial activity against the tested pathogens. The present study supports the view that several ethnomedical plants might be useful as antimicrobial agents resulting in the development of novel drugs for many centuries through ethanopharmacy. (Heinrich 2000, Heinrich and Simon 2001)

\section{References}

[1]. Bauer A.W. Kirby W.M.M. Sherries S.C. and Tunk M 1966. Antibiotic susceptibility of testing by a standard single disc method. Amer. J. Clinical Pathology 36 Pp 492 - 496

[2]. Chopra R. N and Nayar S L 1956 Cedrela toona In: Glossary of Indian medicinal plants Council of Scientific \& Industrial Research India. Pp 56.

[3]. Hiremath S . P Swamy H KS Badamis Patil S and lendonker R L 1997 Antibactrial and antifungal activity of Striga desiflora and Striga orabanchiodes Pharmacology $34 \mathrm{Pp} 48$ - 50.

[4]. Heinrich, M 2000 Ethanobotany and its role in drug development Phytother. Res. 14 Pp $479-488$.

[5]. Heinrich, $\mathbf{M}$ and Simon Gibbon 2001 Ethano Pharmacology in drug development discovery: and analysis of its role and potential contribution J. Pharm. Pharmacol. 53 Pp $425-432$.

[6]. Ruckmani , K. Kavimani, S. B and Karpagams, K. S .1996 Analgesic, Antipyretic and antimicrobial activity of root bark extract of Toddilia asiatica. Ind Drugs Pp $47-49$

[7]. Pradeep ,P, Leena ,P and Bohra, A 2003 Antibacterial potential of Cedrus deodara. Advances in Plant Sciences 16(11) 479-482

[8]. Shankar, Gopal and Joshi 2003 Cedrela toona In: Medicinal plants Oxford A 1 B H publishing co. Pvt. ltd Pp 264.

[9]. Yoganarasimhan 2000.Toona ciliata Roemr var. Ciliata Medicinal Plants of India Srinivasan \& Kokosan Ram , Cyber Media Banglore 2 Pp 549. 